DOI: 10.1515/awutp -2016-0005

\title{
CHANNEL FLOW AND FLOOD ESTIMATE
}

\author{
James A. Adegoke ${ }^{1}$, Mutiu A. Fakunle ${ }^{2}$ \\ ${ }^{1}$ Department of Physics, University of Ibadan, Ibadan \\ ${ }^{2}$ Departyment of Mathematical and Physical Sciences Osun State University, Osogbo.
}

\begin{tabular}{|c|c|}
\hline Article Info & Abstract \\
\hline $\begin{array}{l}\text { Received: } 10.05 .2017 \\
\text { Accepted: } 17.07 .2017\end{array}$ & $\begin{array}{l}\text { The movement of water on the land surface, within channels and through the } \\
\text { soil is dependent on some hydrological factors. For surface flow, the velocity of }\end{array}$ \\
\hline $\begin{array}{l}\text { Keywords: Flood } \\
\text { estimate, Channel flow, } \\
\text { Flow velocity, pipe } \\
\text { roughness and drainage } \\
\text { system. }\end{array}$ & $\begin{array}{l}\text { when roughness increases, it decreases. For a given flow depth, the velocity } \\
\text { decreases as the channel height increases. The construction of sub-surface } \\
\text { drainage helps to remove excess soil water that can cause flood. To model } \\
\text { overland flow, a kinematic-wave approach is applied so that flood prediction could } \\
\text { be made. }\end{array}$ \\
\hline
\end{tabular}

\section{Introduction.}

Drainage systems represent the patterns formed by streams, rivers and lakes in a particular drainage basin. According to [15], if we are to prevent flood (which is an overflow of water that submerges land areas that are usually dry), we need proper diagnosis of drainage systems. Among the factors to consider include climate, topography, surface water hydrology, irrigation and groundwater hydrology (or hydrogeology). Any of these factors or combinations of two or more of these factors may either create or cause drainage problems such as flooding or ponding, or sub-surface problems such as shallow water table, water logging or a combination of these problems. As a result of heavy and sustained rain, rivers or lakes burst their banks and the water spills on the flood-prone plains causing floods and high water tables. The faster the rain water reached the river channels the more likely it is to flood. The nature of the landscape around a river will influence how quickly rain water reached the channel. Several factors that can aid flooding are steep and shallow river channels, lack of vegetation and concrete drainage basins that prevent the water from percolating back to the ground causing water to run faster on the flood plain. Insufficient drainage systems, poor maintenances of water ways and faulty sewers are other factors that can aid flooding 


\section{Theoretical Background and Methodology: Water flow rate and sheet erosion}

Channel flow occurs when the upstream water level of outflow is higher than the water level downstream. Channel flow may be shooting or streaming. This behavior is governed by Froude number $(\mathrm{Fr})$ defined as the ratio of the inertial force to the external field due to gravity [11]. Since Froude number ( $\mathrm{Fr}$ ) is based on the speed length ratio, $\mathrm{Fr}$ can be defined as

$$
\mathrm{Fr}=\frac{\mathrm{V}}{\sqrt{g Y}}
$$

Where $\mathrm{V}=$ average flow velocity $(\mathrm{m} / \mathrm{s})$,

$\mathrm{g}=$ gravitational acceleration $\left(\mathrm{m} / \mathrm{s}^{2}\right)$ and

$\mathrm{Y}=$ hydraulic depth $(\mathrm{m})$ in open channel flows.

But $F r$ can be used to compare wave resistance between bodies of various sizes and shapes in free-surface flow (open channel) and can be used to describe flow as supercritical, subcritical and critical according to $F r$ value. When $F r>1$, it is supercritical and depth is less than critical depth. Small water surface disturbances are always swept downstream in supercritical flow, and the location of the flow control is always upstream. When $F r<1$, it is subcritical and depths greater than critical depth occur. In this state of flow, small water surface disturbances can travel both upstream and downstream, and the control is always located downstream. Flow is critical when $F r=1$ and when the specific energy is a minimum. During critical flow the velocity head is equal to half the hydraulic depth. Fr number provides a measure of the ratio of inertial force to gravitational force. When a change from supercritical to subcritical flow occurs in open flow a hydraulic jump appears, through which the depth increases abruptly in the direction of flow. Flow is described as streaming if $F r<1$ and shooting when $F r>1$. In earthen canals, $F r$ is usually less than 0.2 but the presence of lining in canal increases the flow velocity causing erosion. However, variation in $y$ may result in hydraulic jump which needs to be controlled, to do this, $F r$ must be equal to 0.45 [2].

However, the relative effects of velocity to inertia can be represented with the aid of Reynolds number $(R e)$ a dimensionless number derived through dimensional analysis of the flow is defined as the ratio of inertial forces to viscous forces within fluid which is subject to relative internal movement due to different fluid velocities, can guide one to know when the flow transits 
from laminar to turbulent flow in a particular flow situation, [14] derived analytical solution for laminar flow in channel based on [4] analytical solution for laminar flow in rectangular pipes. For an infinite channel, [1] gave the equation for the flow velocity as

$$
\mathrm{V}=\frac{\mathrm{gS}_{\mathrm{o}} \mathrm{Y}^{2}}{3 v}
$$

Where $\mathrm{V}=$ average flow velocity $(\mathrm{m} / \mathrm{s})$,

$$
\begin{aligned}
& \mathrm{g}=\text { gravitational acceleration }\left(\mathrm{m} / \mathrm{s}^{2}\right), \\
& \mathrm{Y}=\text { hydraulic depth }(\mathrm{m}) \text { in open channel flows } \\
& \mathrm{S}_{\mathrm{o}}=\text { slope }(\mathrm{m}) \text { and } \\
& \mathrm{V}=\text { kinematic viscosity }\left(\mathrm{m}^{2} / \mathrm{s}\right) .
\end{aligned}
$$

But for open channel, Reynolds number $(R e)$ is defined as

$$
\operatorname{Re}=\frac{V \mathrm{D}}{\mu} \text { and } \operatorname{Re}=\frac{\rho \mathrm{VL}}{\mu}
$$

Where $\mathrm{V}=$ maximum velocity of the object relative to the fluid $(\mathrm{m} / \mathrm{s})$

$\mathrm{L}=$ hydraulic diameter when dealing with river systems $(\mathrm{m})$

$\rho=$ density of the fluid $\left(\mathrm{kg} / \mathrm{m}^{3}\right)$

$\mu=$ dynamic viscosity of the fluid $\left(\mathrm{Ns} / \mathrm{m}^{2}\right)$

On rearranging equation (2), the water depth $(\mathrm{Y})$ for a velocity $V$ at a given slope $\left(\mathrm{S}_{\mathrm{o}}\right)$ is

$$
\begin{aligned}
& \mathrm{Y}=\sqrt{\frac{3 \mathrm{~V} v}{\mathrm{gS}_{\mathrm{o}}}} \\
& Y=\frac{6}{\mathrm{R}_{\mathrm{e}}} \frac{\mathrm{V}^{2}}{2 \mathrm{~g}} \frac{1}{\mathrm{~S}_{\mathrm{o}}}
\end{aligned}
$$

Replacing $6 / \mathrm{R}_{\mathrm{e}}$ with $\mathrm{C}_{\mathrm{f}}=$ Coefficient of friction

$$
\mathrm{Y}=\mathrm{C}_{\mathrm{f}} \frac{\mathrm{V}^{2}}{2 \mathrm{~g}} \frac{1}{\mathrm{~S}_{\mathrm{o}}}
$$

Where $\mathrm{Y}=$ water depth above soil surface $(\mathrm{m})$

From equation (2)

$$
\mu=\frac{\mathrm{V} \mathrm{L} \rho}{R_{e}}
$$


The combination of equations (3) and (7) gives the mean flow velocity (V) which relates flow in open channel to the flow in porous media as

$$
V=\sqrt{\frac{\mathrm{R}_{\mathrm{e}} \mathrm{Y}^{2} \mathrm{~S}_{\mathrm{o}} \mathrm{g}}{3 \mathrm{r}}}
$$

$\mathrm{r}=$ pore radius $(\mathrm{m})$.

Transition from laminar to turbulent flow can occur in an open channel and pipeline flow when compare with groundwater flow. The Reynolds number tells if the flow is laminar or turbulent. If the Reynolds number is smaller than the critical Reynolds number $\mathrm{R}_{\mathrm{ecr}}$, which is assumed to be 2300, the flow is laminar. After the laminar flow regime follows the transition region. There the flow switches between laminar and turbulent randomly. When the Reynolds number reaches a certain value, the flow turns from transitional to turbulent. The transitional region ends approximately at the Reynolds number 4000 [6]. In 1843, [18] wrote an equation for laminar flow in pipes as

$$
V_{p}=\mathrm{as}^{\mathrm{u}}
$$

where $\mathrm{V}_{\mathrm{p}}$, = flow velocity

$\mathrm{a}=$ coefficient

s hydraulic gradient and

$\mathrm{u}=$ an exponent whose magnitude is unity

But for circular pipe

$$
V_{p}=\frac{\mathrm{Q}}{\delta \mathrm{A}}=\frac{d^{2} \rho \mathrm{g} \mathrm{s}}{32 \mu}
$$

Where $\mathrm{d}=$ pipe diameter

$\mathrm{Q}=$ flow rate

$\mathrm{A}=$ cross sectional area and $\delta$ is called the soil porosity, which can be determined if the density of solids $\left(\rho_{\mathrm{s}}\right)$ and dry bulk density $\left(\rho_{b}\right)$ are related as follows

$$
\delta=1-\frac{\rho_{\mathrm{b}}}{\rho_{s}}
$$

The porosity ranged from 0.36 to 0.51 for coarse and medium - texture mineral soils. The value of $\rho_{b}$ could be as low as $1000 \mathrm{~kg} / \mathrm{m}^{3}$ when the porosity $(\delta)$ is 0.60 in young clay soils as reported by (5). This says that soils with high bulk density and low porosity will have high permeability 
while those with low bulk density and high porosity will have low permeability. These have a pore - size distribution relation, [3] reported that alluvial soils have porosity that varied from 0.2 to 0.55 .

In practice and design, open channel flow is usually taken place in the rough and turbulent zone, so simple friction formulae can be applied to relate frictional loses to velocity and channel slope. Such equations are Colebrook - White and Manning equations.

\subsection{Colebrook - White Equation}

The Colebrook - White formula can be applied to both transition zone flow and complete turbulence, $\operatorname{Re}>4000$. For transition zone Colebrook - White equation is

$$
\begin{gathered}
\frac{1}{\sqrt{f}}=-2 \log _{10}\left[\frac{k}{3.7 D}+\frac{2.51}{\operatorname{Re} \sqrt{\mathrm{f}}}\right] \\
V=-2 \sqrt{2 \mathrm{~g} \mathrm{D} \mathrm{s}} \log _{10}\left[\frac{k}{3.7 D}+\frac{2.51 \mathrm{v}}{\mathrm{D} \sqrt{2 \mathrm{~g} \mathrm{D} \mathrm{S}}}\right] \\
V=-4 \sqrt{2 \mathrm{~g} \mathrm{R}_{\mathrm{w}} \mathrm{S}_{\mathrm{o}}} \log _{10}\left[\frac{k}{14.8 R_{w}}+\frac{0.314 \mathrm{v}}{\mathrm{R}_{\mathrm{w}} \sqrt{2 \mathrm{~g} \mathrm{R}_{\mathrm{w}} \mathrm{S}_{\mathrm{o}}}}\right]
\end{gathered}
$$

Where $\mathrm{k}=$ Colebrook roughness factor

$$
\begin{aligned}
& \mathrm{V}=\text { kinematic viscosity of water } \\
& \mathrm{D}=\text { diameter of circular pipe } \\
& \mathrm{R}=\text { hydraulic radius of flow at a cross }- \text { section }=\frac{A_{w}}{p_{w}}=\frac{\mathrm{D}}{4} \text { for full circular pipe }(\mathrm{m}) \\
& \mathrm{f}=\text { Darcy friction factor based on } \mathrm{D} \\
& \mathrm{A}_{\mathrm{w}}=\text { wetted cross }- \text { sectional area } \\
& \mathrm{P}_{\mathrm{w}}=\text { wetted cross sectional perimeter and } \\
& \mathrm{S}=\text { channel bed slope }
\end{aligned}
$$

The value of roughness for common pipe materials is in the interval $0.6 \mathrm{~mm}$ to $6.00 \mathrm{~mm}$ [8]. 


\subsection{Manning's Formula}

Manning's formula is an empirical formula estimating the average velocity of a liquid flowing in open channel. For complete turbulence at high Re Manning formula is

$$
V=\frac{\mathrm{R}^{\frac{2}{3}} \mathrm{~S}^{\frac{1}{2}}}{\mathrm{n}}
$$

Where $\mathrm{V}=$ Mean velocity $(\mathrm{m} / \mathrm{s})$

$\mathrm{n}=$ manning coefficient of roughness

$\mathrm{R}=$ hydraulic radius $(\mathrm{m})$

$\mathrm{S}=$ slope or gradient of pipe $(\mathrm{m} / \mathrm{m})$

\section{Sheet Flow Modelling}

Consider a flow over a sloping plane, applying the kinematic depth - flow approximation;

$$
q=\mathrm{K} \mathrm{D}^{\mathrm{m}}
$$

where $\mathrm{D}=$ the flow depth.

The applicability of this equation is based on open channels flow whose depth of flow does not change over time or constant during time interval under consideration and to flow in smooth sloping plane.

In Kinematic - wave approach, modelling has been replaced by parameter estimate and since Chezy equations apply to turbulent open channel flow, we can write

$$
q=\mathrm{VD}=\mathrm{CD}^{\frac{3}{2}} S_{o}^{\frac{1}{2}}
$$

$\mathrm{D}=$ hydraulic radius and $C=\frac{18 \log 12 \mathrm{D}}{\mathrm{k}}$ is called Chezy coefficient

Comparison of (12) and (13) shows

$$
K=\mathrm{CS}_{\mathrm{o}}^{\frac{1}{2}}
$$

which means that for turbulent flow, the value of $\mathrm{m}=3 / 2$ and $V=\mathrm{KD} \mathrm{D}^{(\mathrm{m}-1)}$

Using Manning equation for overland flow we have 


$$
q=\mathrm{VD}=\frac{1}{\mathrm{n}} \mathrm{D}^{\frac{5}{3}} \mathrm{~S}_{\mathrm{o}}^{\frac{1}{2}}
$$

Comparing equations (12) and (15), it follows that

$$
K=\frac{1}{\mathrm{n}} \mathrm{S}_{\mathrm{o}}^{\frac{1}{2}}
$$

Note that $\mathrm{m}=5 / 3$ for turbulent flow (Linsley et al. [16]

For case of laminar flow, Poiseuiolle equation is

$$
q=\mathrm{VD}=\left(\frac{\mathrm{g} \mathrm{S}_{\mathrm{o}}}{2 \mathrm{~V}}\right) \mathrm{D}^{3}
$$

Comparing equations (12) and (17) we have

$$
K=\frac{\mathrm{g} \mathrm{S}_{\mathrm{o}}}{2 \mathrm{~V}}
$$

From equations (12) and (17), [13] were of the opinion that $\mathrm{m}=3$ for laminar flow, [19] assumed a constant flow velocity in which the value of $m=1$ is justified. This implies that $K=V$. Since Reynold number help to predict flow pattern in different fluid flow situation, then open channel flow is characterized by Reynold number.

\section{Sediment Transportation}

This is the movement of solid particles such as sand, gravel, boulders, mud, or clay by water, air, or ice and the force of gravity along the sloping surface on which they are resting. Sediment transport due to fluid motion occurs in rivers, oceans, lakes seas and other water bodies due to currents and tides. Sediment transport due only to gravity can occur on sloping surfaces such as hillslope, scarps, cliffs and the continental shelf - continental slope boundary. Because of the viscosity and higher density of water sediments moved are larger. In typical rivers, the largest carried sediment is of sand and grained size, but large floods can carry cobbles and boulders.

For a given volume of water - sediment mixture, the suspended concentration is the ratio of the weight of dry sediment to the weight of the water- sediment mixture expressed in parts per millions (ppm)

$$
p p m=\frac{\text { weight of dry sediment }}{\text { weight of water and sediment mixture }} \times 10^{6} \text {, }
$$




$$
p p m=\frac{\mathrm{Q}_{\mathrm{m}} \rho_{m}}{Q \rho_{\mathrm{w}}} \times 10^{6}
$$

This concentration varies with the vertical flow depth and lower near the water surface but higher near the stream bed. The coarsest - sediment fractions has greatest variation in concentration with flow depth while the finer fractions such as silt and clay show a tendency for a nearly uniform distribution of suspended sediment concentration with flow depth. If concentration of suspended sediment exceeds 20,000 ppm by mass, then the flow is termed sediment laden and if is 10,000 or less, it is sediment free, [3].

Sediment transport can be predicted by computing bed material load consisting of bed load and suspended bed material load, [9] find a simple and a reliable formula for bed material load over the full width $b$ of the channel as

$$
\mathrm{Q}_{\mathrm{m}}=\mathrm{Tb}
$$

But bed material of a channel will not move if

$$
Y=\frac{\mu \mathrm{R} \mathrm{S}}{\rho_{\mathrm{r}} d} \leq 0.047 \mathrm{~m}
$$

If Y exceed $0.047 \mathrm{~m}$, sediment particles on the channel bed begin to slide, roll or jump over and near the bed. This behavior is termed bed - load transport, which [17] addressed as

$$
X=\mathrm{A}_{1}(\mathrm{Y}-0.047)^{\frac{3}{2}}
$$

where

$$
\begin{aligned}
& \mathrm{A}_{1}=\mathrm{a} \text { factor with an average value of } 8 \text { and } \\
& \mathrm{X}=\text { a dimensionless called transport parameter given by } \\
& \qquad X=\frac{\mathrm{T}}{\sqrt{\rho_{r} g \mathrm{~d}^{3}}}
\end{aligned}
$$

$\mathrm{T}=$ transport of soil material expressed in solid volume per second for one unit width of channel,

$\mathrm{d}=\mathrm{d}_{50}=$ median grain diameter $(\mathrm{m})$

$\mathrm{R}=$ Hydraulic radius, defined as the ratio of the wetted area to the wet perimeter (m)

$$
\rho_{r}=\rho_{\mathrm{m}}-\frac{\rho_{w}}{\rho_{m}}
$$

$\rho_{w}=$ density of water $\left(\mathrm{kg} / \mathrm{m}^{3}\right)$ 


$$
\rho_{m}=\text { mass density of the bed material }\left(\mathrm{kg} / \mathrm{m}^{3}\right)
$$

Therefore $X=0.05 \mathrm{Y}^{\frac{5}{2}}$.

\section{Result and discussion}

Characteristics of flow in channels consist of classification of flow, flow velocity, Manning's roughness (n), Froude number (Fr), Reynolds Number (Re), bottom slope, pipe roughness e. t. c were calculated using Microsoft excel program whereby iterations were better performed other than manual calculators. The results of which were presented in Figs. $1-12$ below and tables 1 and 2 respectively.

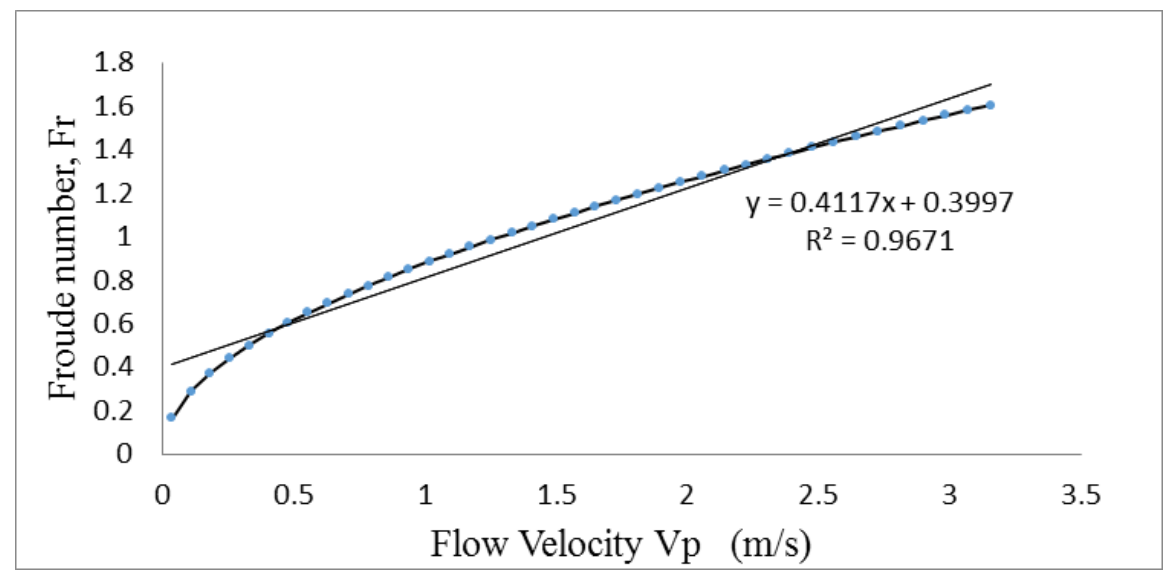

Fig.1: Flow prediction using Froude's number. $0.005 \leq \mathrm{Y} \leq 0.4 \mathrm{~m}(\mathrm{Y}=$ water depth $)$

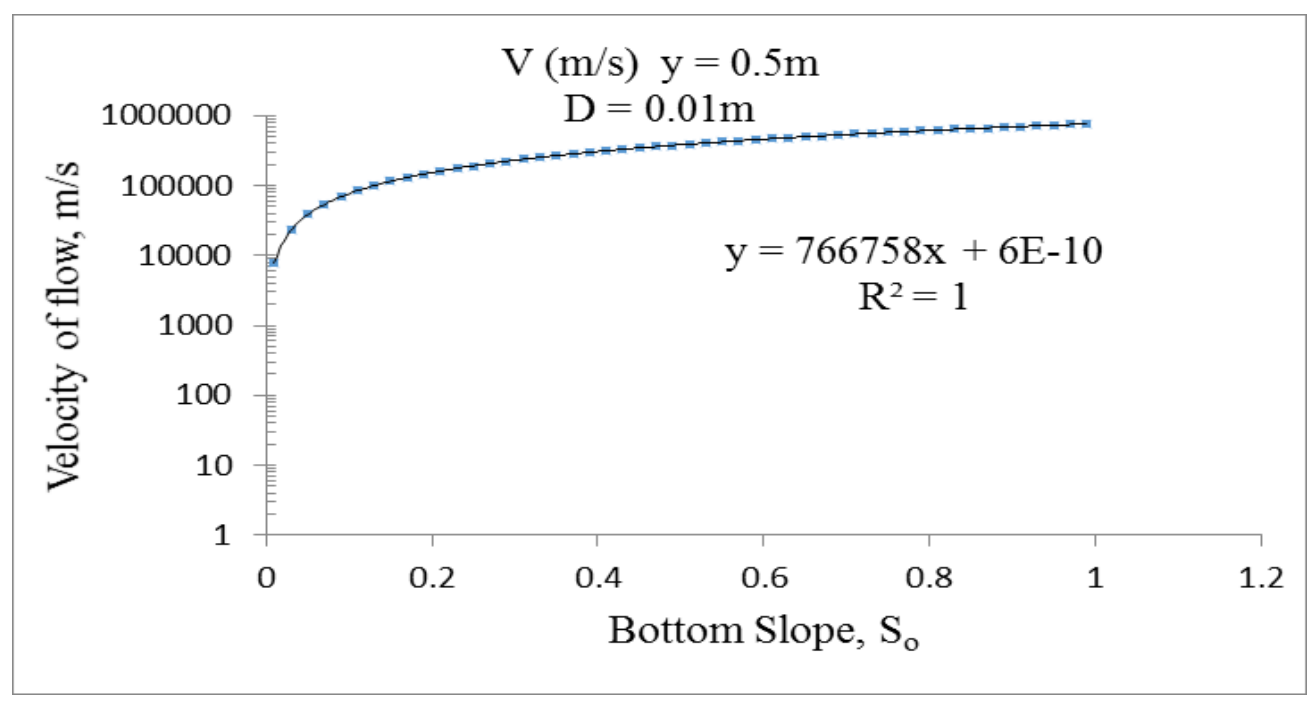

Fig. 2: Flow relation using modified Boussinesq equation for water depth of $0.01 \mathrm{~m}$ and channel depth of $0.5 \mathrm{~m}$. (Equation 3). 


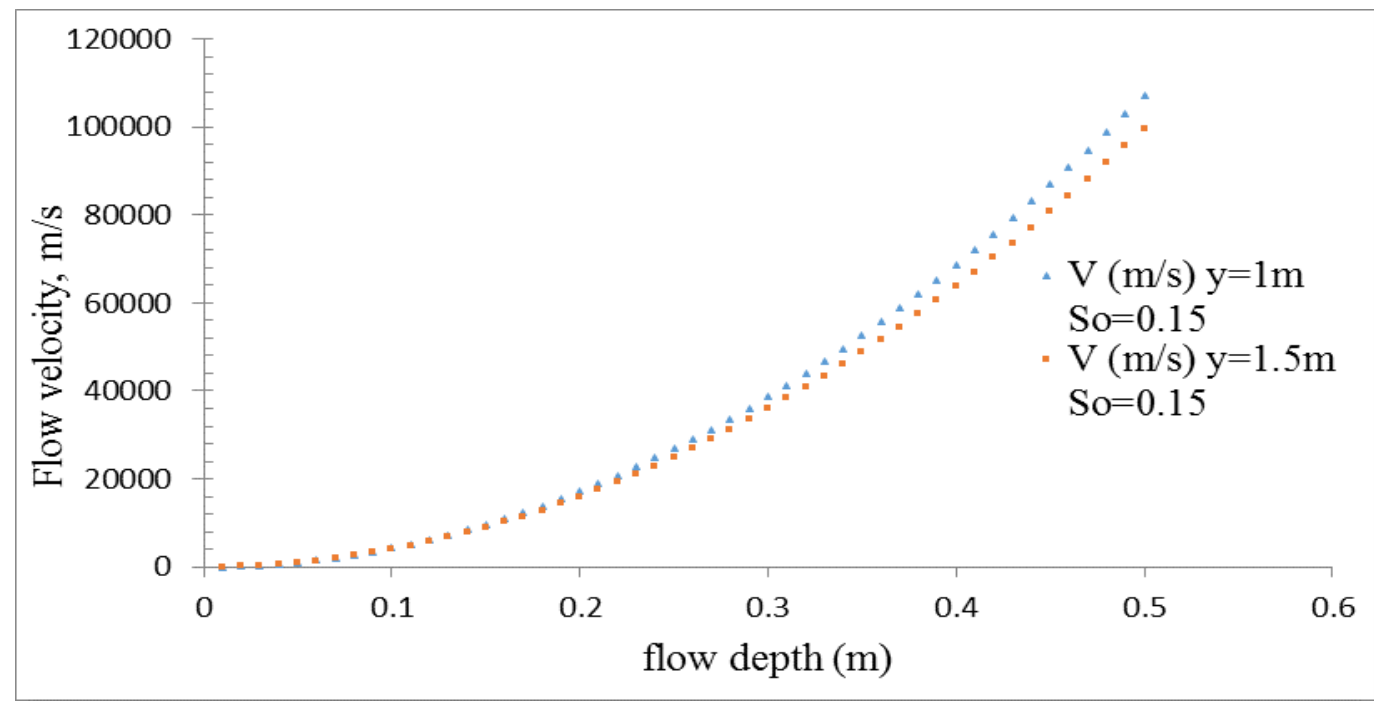

Fig 3: Flow relation using modified Boussinesq equation for bottom slope of 0.15 and channel height at $1 \mathrm{~m}$ and $1.5 \mathrm{~m}$ (Equation 3).

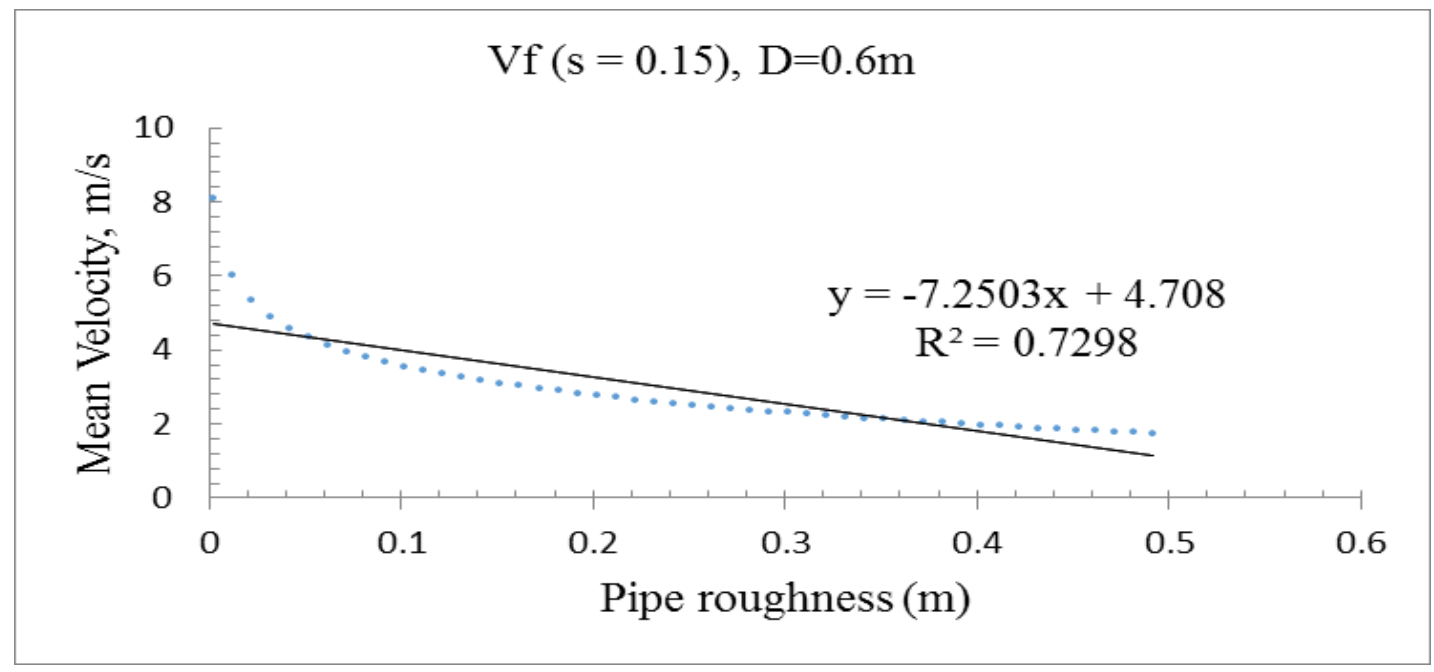

Fig. 4: Flow curve for full flowing pipe using Colebrook-white equation for a pipe diameter of $0.6 \mathrm{~m}$ and a gradient of 0.15 for different pipe roughness.

The mean velocity is inversely proportional to the pipe roughness (i.e., the mean velocity reduces as the roughness of the pipe increases). 


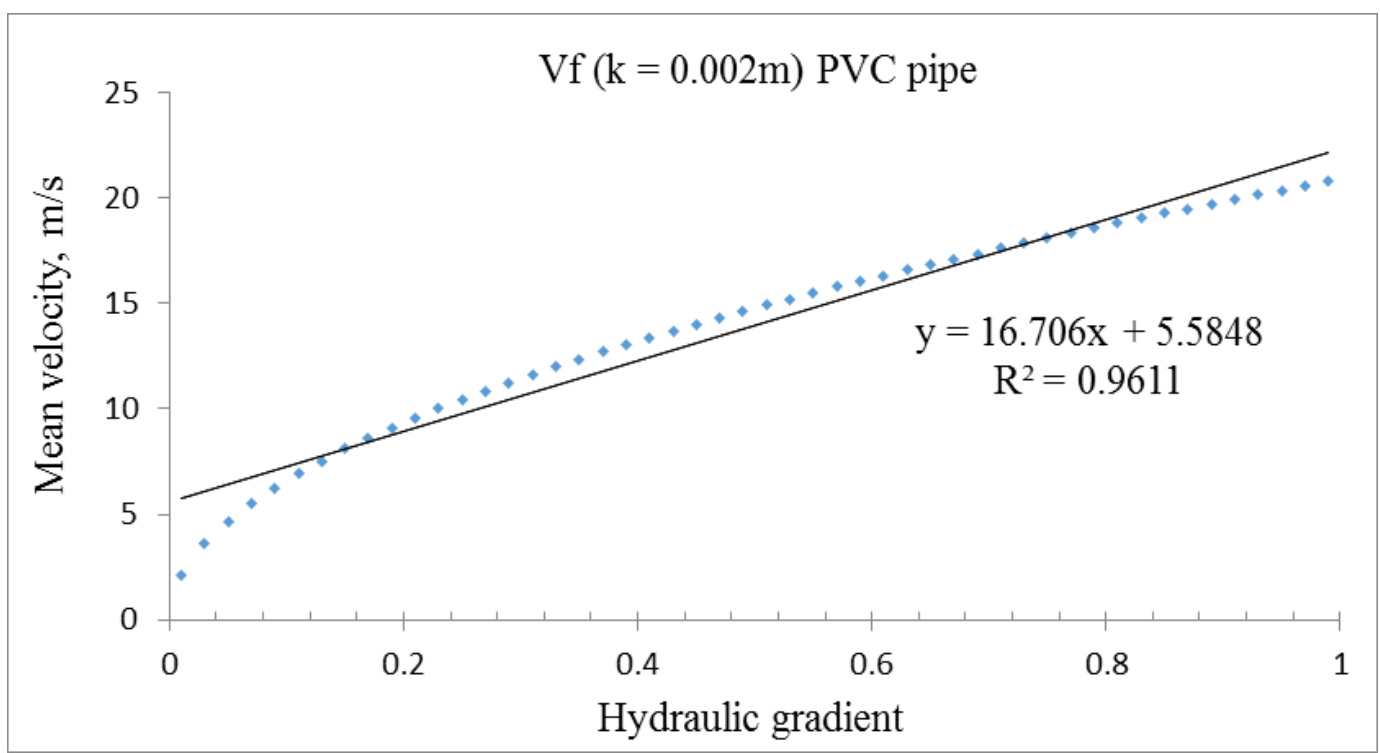

Fig.5: Flow curve for full flowing pipe using Colebrook-white equation for a PVC pipe with roughness of $0.002 \mathrm{~m}$ and pipe diameter of $0.6 \mathrm{~m}$.

The mean velocity is seen to increase as the hydraulic gradient increases.

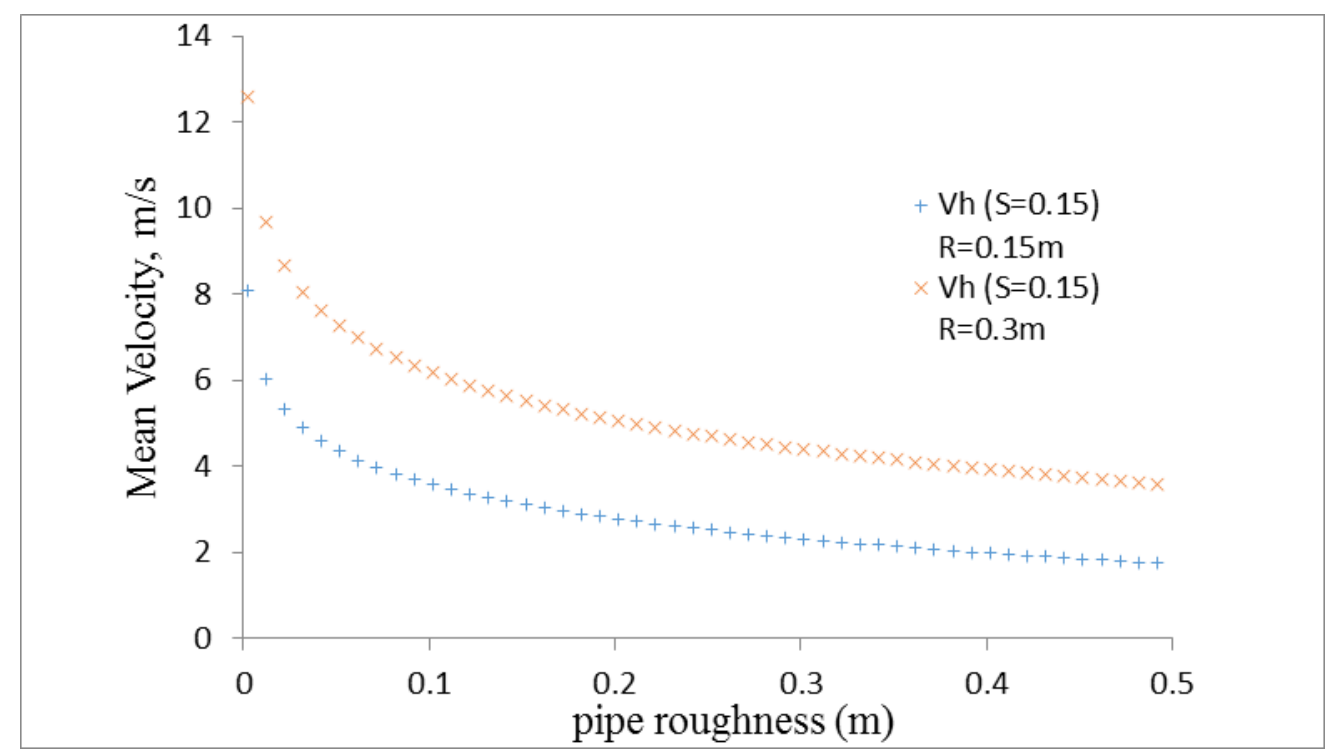

Fig. 6: Flow curve for partially full (or non-circular) pipe using Colebrook-white equation with a gradient of 0.15 and a hydraulic radius of $0.15 \mathrm{~m}(\mathrm{D} / 4)$ and $0.3 \mathrm{~m}$. 


\section{Surface Flow}

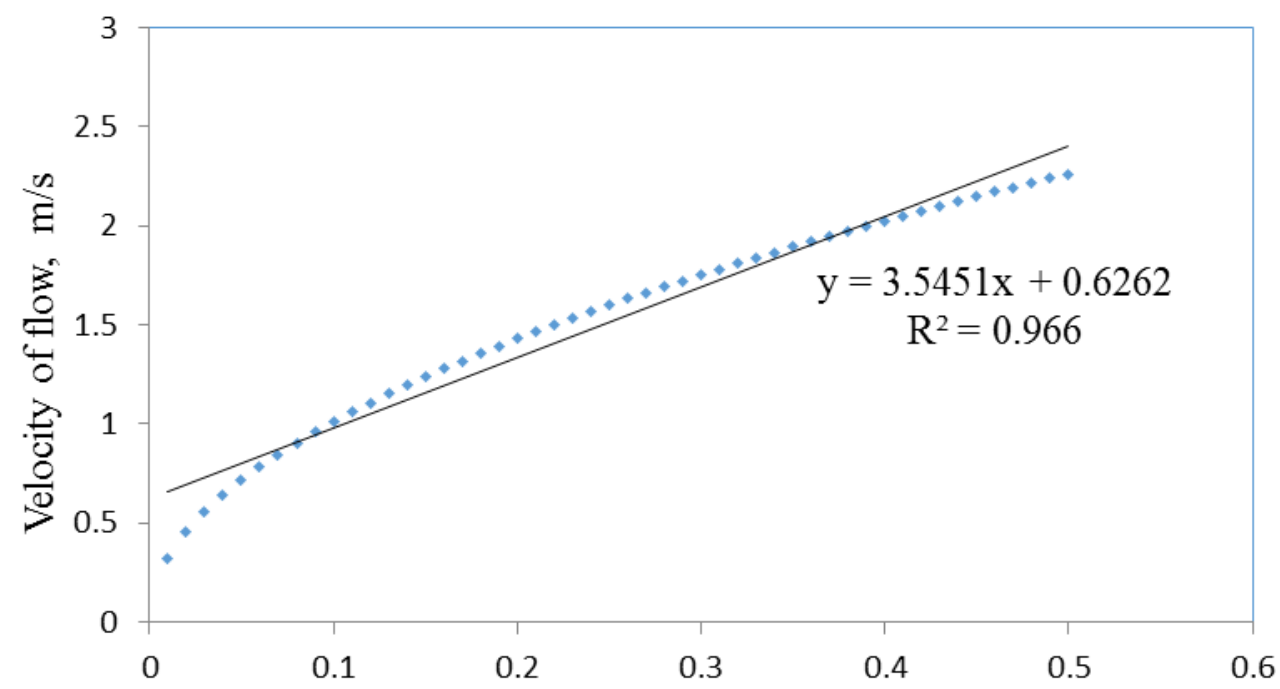

Flow depth, D (m)

Fig. 7: Flow velocity versus depth using Chezy equation for turbulent flow $(\mathrm{k}=3.2)$

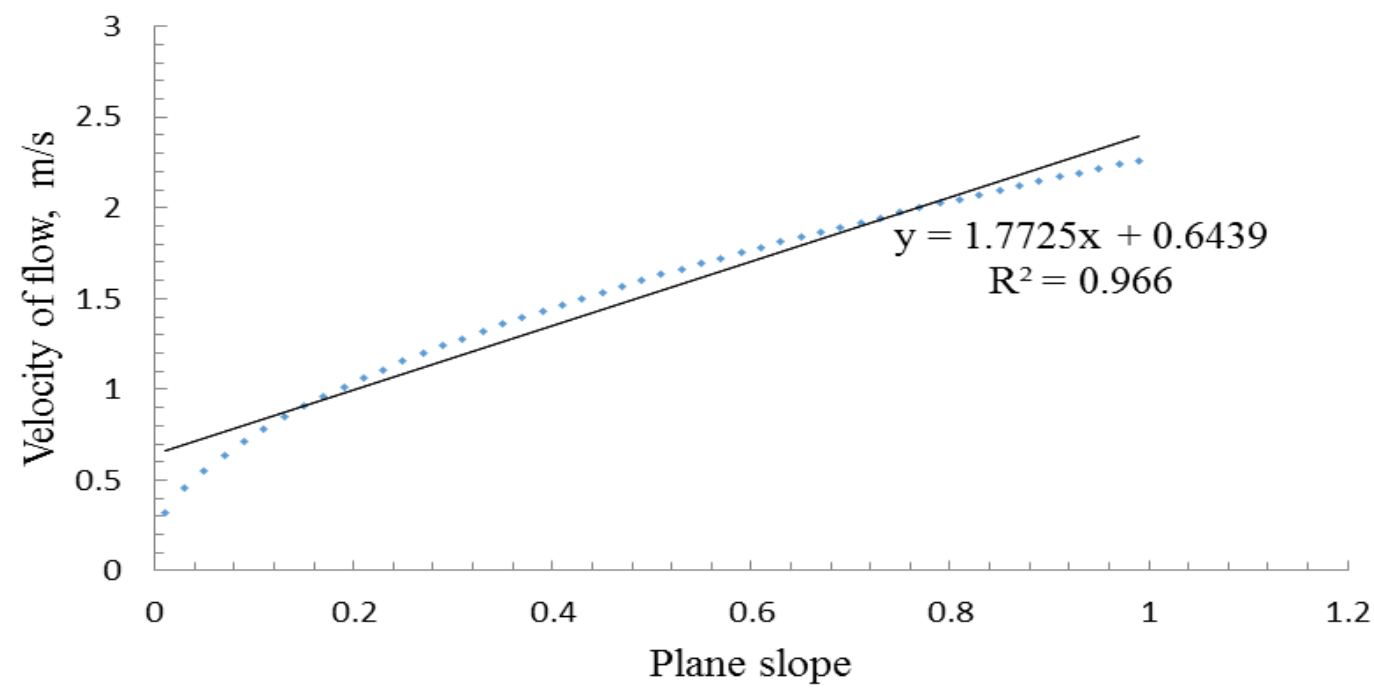

Fig. 8: Velocity variation with plane slope using Chezy equation. 
Table 1: Velocity variation at given hydraulic radius with roughness using Manning's equation $(0.01 \leq n \leq 0.21)$.

\begin{tabular}{|c|c|c|}
\hline $\mathrm{n}$ & $\mathrm{Vm}(\mathrm{S}=0.15)$ & $\mathrm{Vm}(\mathrm{S}=0.15)$ \\
\hline & $\mathrm{R}=0.15$ & $\mathrm{R}=0.3$ \\
\hline 0.01 & 10.93385060 & 17.35640595 \\
\hline 0.02 & 5.466925302 & 8.678202976 \\
\hline 0.03 & 3.644616868 & 5.785468650 \\
\hline 0.04 & 2.733462651 & 4.339101488 \\
\hline 0.05 & 2.186770121 & 3.471281190 \\
\hline 0.06 & 1.822308434 & 2.892734325 \\
\hline 0.07 & 1.561978658 & 2.479486564 \\
\hline 0.08 & 1.366731326 & 2.169550744 \\
\hline 0.09 & 1.214872289 & 1.928489550 \\
\hline 0.10 & 1.093385060 & 1.735640595 \\
\hline 0.11 & 0.993986419 & 1.577855086 \\
\hline 0.12 & 0.911154217 & 1.446367163 \\
\hline 0.13 & 0.841065431 & 1.335108150 \\
\hline 0.14 & 0.780989329 & 1.239743282 \\
\hline 0.15 & 0.728923374 & 1.157093730 \\
\hline 0.16 & 0.683365663 & 1.084775372 \\
\hline 0.17 & 0.643167683 & 1.020965056 \\
\hline 0.18 & 0.607436145 & 0.964244775 \\
\hline 0.19 & 0.575465821 & 0.913495050 \\
\hline 0.20 & 0.546692530 & 0.867820298 \\
\hline 0.21 & 0.520659553 & 0.826495521 \\
\hline & & \\
\hline
\end{tabular}

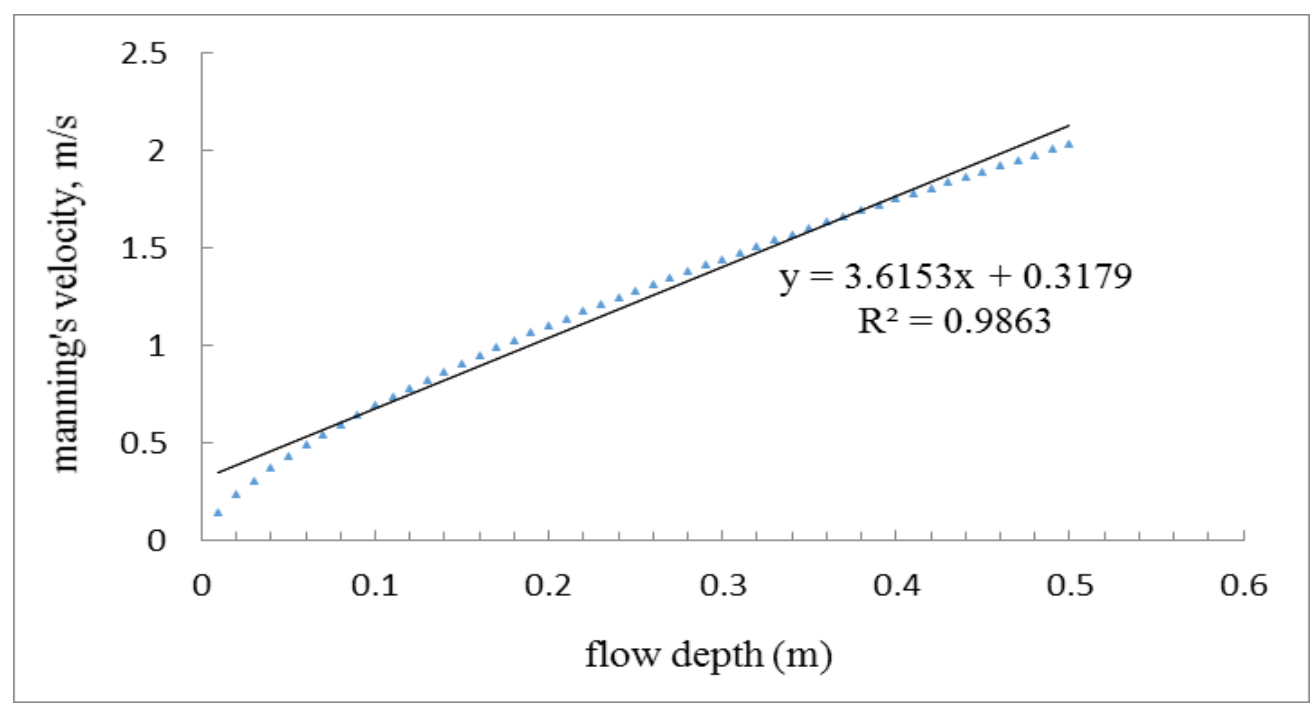

Fig. 9: Turbulent flow using manning's equation for a bottom slope of 0.15 with $\mathrm{k}=3.227$. 


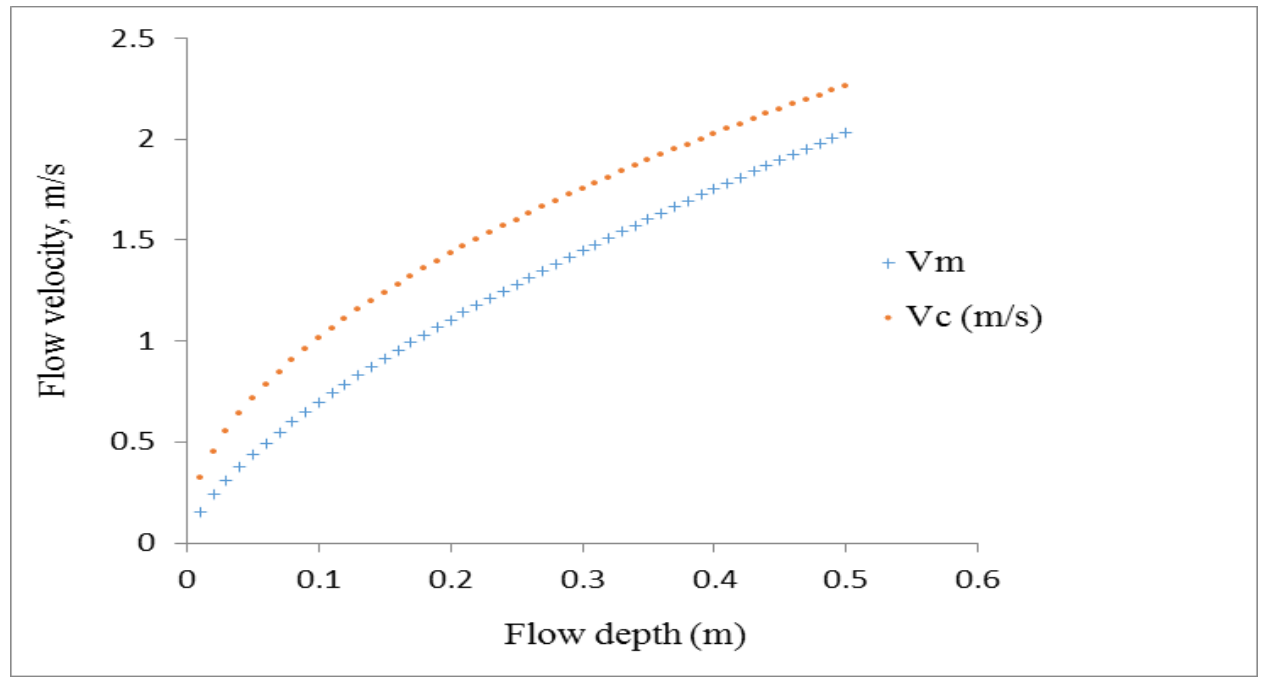

Fig.10: Turbulent flow using Chezy's and Manning's equation for $k=3.2$ and 3.23 respectively.

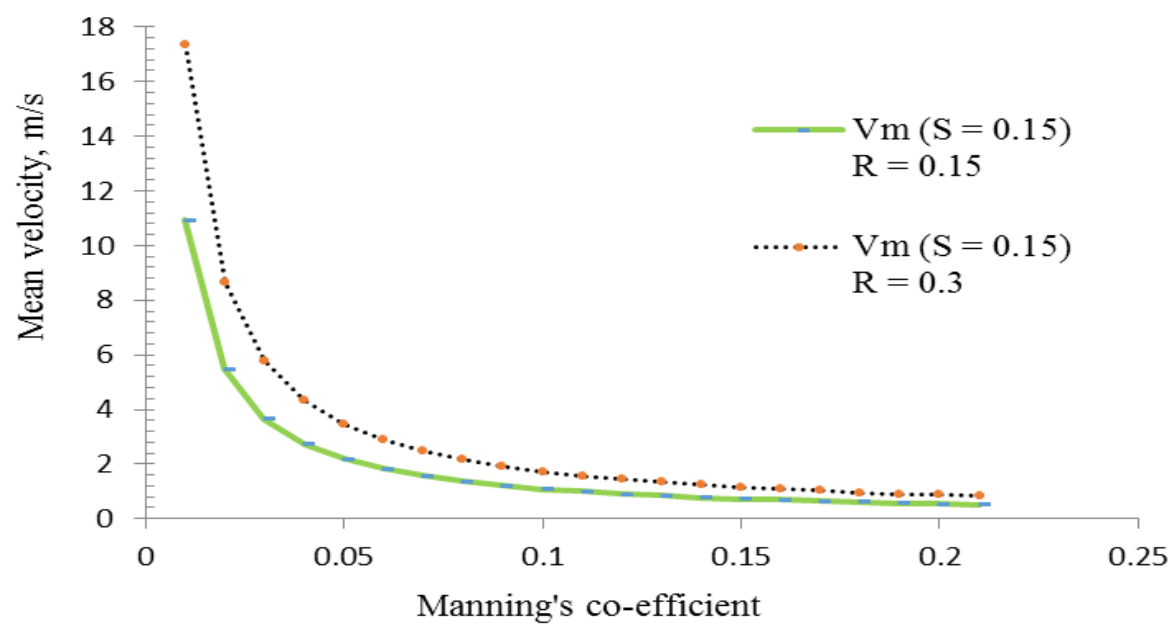

Fig.11: Flow variation with Manning's roughness for varied hydraulic radius. 


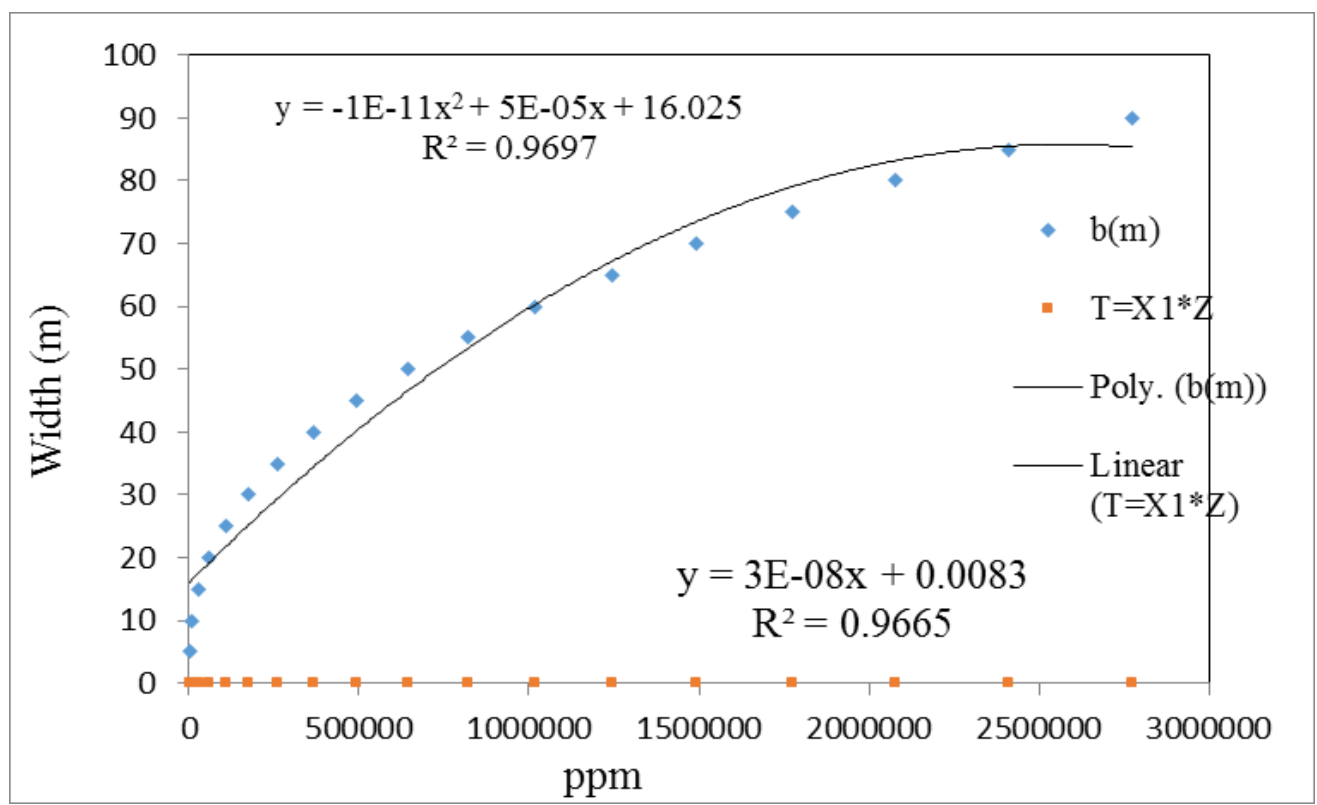

Fig. 12: Sediment transportation variation with width of channel

Table 2: Sediment transportation of different liquid at different depth.

\begin{tabular}{|c|c|c|c|c|c|c|c|c|c|c|c|c|c|}
\hline Ppm & $\mathrm{Qm}$ & $\mathrm{Q}$ & $\rho_{\mathrm{m}}$ & $\rho_{\mathrm{w}}$ & $\mathrm{Y}$ & $\mathrm{g}$ & $\mathrm{d}$ & $\rho_{\mathrm{r}}$ & $\mathrm{X} 1$ & $\mathrm{X}$ & $\mathrm{Z}$ & $\mathrm{T}=\mathrm{X} 1 * \mathrm{Z}$ & $\mathrm{b}(\mathrm{m})$ \\
\hline 1054.846 & 0.0024 & 5.982 & 2660 & 1000 & 0.05 & 9.81 & 0.2 & 1.66 & 0.00131 & $2.80 \mathrm{E}-05$ & 0.36094 & 0.000474 & 5 \\
\hline 9140.21 & 0.0207 & 6.013 & & & 0.055 & & & & 0.00572 & $3.55 \mathrm{E}-05$ & 0.36094 & 0.002066 & 10 \\
\hline 28256.8 & 0.0642 & 6.044 & & & 0.06 & & & & 0.01186 & $4.41 \mathrm{E}-05$ & 0.36094 & 0.00428 & 15 \\
\hline 61074.79 & 0.1395 & 6.074 & & & 0.065 & & & & 0.01932 & $5.39 \mathrm{E}-05$ & 0.36094 & 0.006973 & 20 \\
\hline 109716.7 & 0.2518 & 6.105 & & & 0.07 & & & & 0.0279 & $6.48 \mathrm{E}-05$ & 0.36094 & 0.010072 & 25 \\
\hline 175965.6 & 0.4059 & 6.135 & & & 0.075 & & & & 0.03748 & $7.70 \mathrm{E}-05$ & 0.36094 & 0.013529 & 30 \\
\hline 261365.1 & 0.6058 & 6.166 & & & 0.08 & & & & 0.04796 & $9.05 \mathrm{E}-05$ & 0.36094 & 0.01731 & 35 \\
\hline 367277.3 & 0.8556 & 6.197 & & & 0.085 & & & & 0.05926 & 0.000105 & 0.36094 & 0.021389 & 40 \\
\hline 494919.5 & 1.1586 & 6.227 & & & 0.09 & & & & 0.07133 & 0.000122 & 0.36094 & 0.025747 & 45 \\
\hline 645390.1 & 1.5183 & 6.258 & & & 0.095 & & & & 0.08413 & 0.000139 & 0.36094 & 0.030366 & 50 \\
\hline 819687.7 & 1.9378 & 6.288 & & & 0.1 & & & & 0.09761 & 0.000158 & 0.36094 & 0.035232 & 55 \\
\hline 1018725 & 2.42 & 6.319 & & & 0.105 & & & & 0.11175 & 0.000179 & 0.36094 & 0.040333 & 60 \\
\hline 1243340 & 2.9679 & 6.35 & & & 0.11 & & & & 0.1265 & 0.000201 & 0.36094 & 0.04566 & 65 \\
\hline 1494304 & 3.5841 & 6.38 & & & 0.115 & & & & 0.14186 & 0.000224 & 0.36094 & 0.051202 & 70 \\
\hline 1772333 & 4.2714 & 6.411 & & & 0.12 & & & & 0.15779 & 0.000249 & 0.36094 & 0.056952 & 75 \\
\hline 2078086 & 5.0322 & 6.441 & & & 0.125 & & & & 0.17427 & 0.000276 & 0.36094 & 0.062902 & 80 \\
\hline 2412178 & 5.8689 & 6.472 & & & 0.13 & & & & 0.1913 & 0.000305 & 0.36094 & 0.069046 & 85 \\
\hline 2775181 & 6.7841 & 6.503 & & & 0.135 & & & & 0.20884 & 0.000335 & 0.36094 & 0.075379 & 90 \\
\hline
\end{tabular}




\section{Discussions}

Observations indicated that the friction factor depended pipe roughness, velocity pipe diameter, viscosity of the fluid flowing and Reynolds number of flow [19]. The channel roughness is not controlled by the size of individual particles, but it is affected by the concentration of suspended sediment. Larger concentrations being associated with smaller value of roughness. Causes of flood may include extreme changes in the river catchments and material deposition along the river bed Channels re categorized as compound channel when flood occurs. In compound channels, three types of low can occur; overbank, bank fill and in bank. Overbank occurs when flow over spill into the flood plain. During flooding the suspended load decreases channel resistance and thus causes an increase in velocity.

In Fig.1, the Froude number (Fr) increases with flow velocity increases an indication of supercritical when Fr is greater than 1. In Fig.2, the logarithm of the velocity of flow was plotted against the bottom slope. The velocity of flow increases as the bottom slope increases when channel's width was considered at $10 \mathrm{~m}$. However, when channel's height was considered at $1.0 \mathrm{~m}$ and $1.5 \mathrm{~m}$ (Fig. 3), the flow velocity varied directly water depth (i.e., the higher the water depth, the greater the velocity). An indication that when the channel's was increased the flow velocity however, could be lowered. Adegoke and Egbeyale (2011) have considered when the channel height was in synchrony with the water depth. Hence, the channel height was considered above the given limit of the water depth (i.e. above $0.5 \mathrm{~m}$ ). The measured velocity in an open channel will always varied across the channel section because of friction along the boundary. The velocity distribution in a channel section depends on the factors such as the unusual shape of the section, the roughness of the channel and the presence of bends. At turbulent $\operatorname{Re}>4000$ the flow is at high velocity and the flow is characterized by the irregular movement of the particles of the fluid and average motion is in the direction of the flow. In Fig. 4 the mean velocity is inversely proportional to the pipe roughness (i.e., the mean velocity reduces as the roughness of the pipe increases). But when pipe roughness was $0.002 \mathrm{~m}$ and pipe diameter still remain the mean velocity is seen to increase as the hydraulic gradient increases as shown in Fig.5. This is an indication that roughness has an effect on the fluid flowing. The result of Fig. 6 gave the same result for $\mathrm{D}=0.6 \mathrm{~m}$ which implies that hydraulic radius $=$ Wetted area divided by the wetted perimeter, $\mathrm{R}=\mathrm{D} / 4$. This means that when the hydraulic radius varied the mean velocity 
decreases. When flow velocity was plotted against flow depth using Chezy's equation, at water flow depth was between 0.01 and $0.5 \mathrm{~m}$, and the slope (hydraulic gradient) used was between 0.01 and 0.99 which gave rise to $\mathrm{q}$ (water flow rate) and $\mathrm{V}$ (flow velocity) at $\mathrm{m}=3 / 2$ (turbulent flow) (Fig. 7). There was a kind of transition from laminar to turbulent. Table 1 shows Velocity variation at given hydraulic radius with roughness using Manning's equation $(0.01 \leq n \leq 0.21)$. The graph of manning's velocity with flow depth indicated that the velocity increases with depth (Fig. 9). When Chezy's and Manning equations were used and their flow velocity were plotted against flow depth (Fig. 10), the flow velocity increases with flow depth but Chezy's equation predicted higher velocity of flow than Manning's own. In fig. 11, flow variation was plotted against Manning's coefficient for varied hydraulic radius, a drastic reduction in flow velocity was observed when roughness increases from 0.01 to $0.02 \mathrm{~m}$. Also relative small reduction in flow velocity as the roughness increases. When the width of channel increases sedimentation transport also increases as in fig. 12. Table 2 is showing sediment transport of different liquids at different depths.

\section{Conclusion}

For overland flow, the velocity of flow increases with the bottom slope of the channel as well as the flow depth but decreases as the roughness increases. For given flow depth, the velocity decreases as the channel height increases. In practice, drains are seldom completely clean. This is because some siltation always occurs, notably during and shortly after construction owing to the entrance of soil particles from the yet unsettled soil and/or envelope around the pipe when relatively large amounts of water enter. A layer of sediment usually forms over time. This sediment should be removed by maintenance, where it reduces the transport capacity of the pipe too much. Entry of soil and plant roots can be prevented largely by a good envelope around the drains, by construction at sufficient depth.

\section{References}

[1] J. A. Adegoke and G. B. Egbeyale, A computation of laminar flow in open channels and its application to sheet erosion, African Journal of Physical Science 4(1) (2011), 91-100.

[2] Th. M. Boers, Rainwater Harvesting in Arid and Semi-arid Zones, Wageningen, The Netherlands, International Land Reclamation and Improvement Institute (ILRI), 1994, 132. 
[3] M. G. Bos, Discharge Measurement Structures, International Institute for Land Reclamation and Improvement, 2nd ed., Wageningen, 1978.

[4] V. J. Boussinesq, Memoir on the influence of friction in the regular movement of fluids, J. Math, Pure and Appl. 1868, 13

[5] H. M. H. Braun and R. Kruijine, Soil conditions, Drainage Principles and Applications, International Institute for Land Reclamation and Improvement, Wageningen, 2nd ed., 1994, 77-109.

[6] Cengel, Y. Cimbala, J., Fluid Mechanics: Fundamentals and Applications. McGraw-Hill, 2006, 956.

[7] V. T. Chow, Open-channel Hydraulics, McGraw-Hill Book Co., New York, 1959, 680

[8] Drainage Services Department, Sewerage Manual: Key Planning Issues and Gravity Collection System, 3rd ed., Part I, 2013.

[9] F. Engelund and E. Hansen, A Monograph on Sediment Transport in Alluvial Streams, Teknisk Forlag, Copenhagen, Denmark, 1967.

[10] F.A.O., Guidelines and Computer Programs for the Planning and Design of Land Drainage Systems, Irrigation and Drainage, W. H. Van Der Molen, J. M. Beltrán and W. J. Ochs, eds., 200562.

[11] Federal Ministry of Works: Federal Republic of Nigeria, Drainage Design Highway Manual Part 1: Design, Volume IV, 2013.

[12] F. M. Henderson and R. A. Wooding, Overland flow and groundwater flow from a steady rainfall of finite duration, Journal of Geophysical Research 69(8) (1964) 1531-1540.

[13] W. Horton, T. Tajima, J. Q. Dong, Y. Kishimoto and J. Y. Kim, Ion transport analysis of a high beta-poloidal JT-60U discharge, Phys. Plasma 1 (1994), 1-5.

[14] G. P. Kruseman and N. A. de Ridder, Analysis and Evaluation of Pumping Test Data, International Institute for Land Reclamation and Improvement (IILRI) Publication, Vol. 47, 1994, 200 - 253, Wageningen, The Netherlands

[15] R. K. Linsley, M. A. Kohler and J. L. H. Paulhus, Hydrology for Engineers, $3^{\text {rd }}$ ed., McGraw-Hill, New York, 1982, 508.

[16] E. Meyer-Peter and R. Müller, Formulas for bed-load transport, Proceedings of the 2nd Meeting of the International Association for Hydraulic Structures Research, 1948, 39-64. 
[17] J. L. M. Poiseuiolle, Experimental research on the movement of liquids: Proceedings of the Academy of Sciences vol. IX 1843, 433 - 534

[18] Y. Zarmi, J. Ben Asher and T. Greengard, Constant velocity kinematic analysis of an infiltrating micro catchment hydrograph, Water Resources Research 19(1) (1983), 277283.

[19] J. K. Vennard. Elementary Fluid Mechanics 4th ed., McGraw-Hill, New York, 1961, 348 -392 . 